DOI: 10.17707/AgricultForest.64.4.13

\begin{abstract}
Teofil GAVRIĆ, Sabrija ČADRO, Drena GADŽO, Mirha ĐIKIĆ, Muamer BEZDROB, Zoran JOVOVIĆ, Josip JURKOVIĆ, Saud HAMIDOVIĆ ${ }^{1}$
\end{abstract}

\title{
INFLUENCE OF METEOROLOGICAL PARAMETERS ON THE YIELD AND CHEMICAL COMPOSITION OF COMMON BUCKWHEAT (Fagopyrum esculentum Moench)
}

\begin{abstract}
SUMMARY
Common buckwheat (Fagopyrum esculentum Moench) is an annual plant from Polygonaceae family which is well known as pseudocereal with high nutritional value. The yield and quality of the buckwheat`s kernel depend on weather conditions, mainly due to variations in the air temperatures and precipitation during the growing period. The aim of this study was to determine the impact of some metrological parameters on yields and chemical compositions in the kernel of buckwheat. Field experiments were conducted during three years (2011, 2012 and 2013) in the village Donje Selo, near Ilijaš. In this study grain yield, protein content, sludge, fats, mineral matter, cellulose and total phenols were determined. Experimental results suggested that the weather conditions in different years of the research have a significant impact on the yield and the chemical composition of the kernel. The yield of buckwheat varied from the year to year and ranged from 0.98 to 1.29 tons per hectare. Contents of protein and starch were also significantly dependent on the year of the research, as well as the content of phenol in the kernel. High total phenolic content was recorded in the year with the highest average monthly air temperature.

Keywords: buckwheat, meteorological parameters, yield, chemical composition

\section{INTRODUCTION}

Common buckwheat (Fagopyrum esculentum Moench) is an annual plant and belongs to botanical family Poligonaceae. It is a very old plant that is used as human or animal feed for more than 7.000 years (Gadžo et al., 2016). It originates from Asia and it was introduced to Europe in the 15th century. in agriculture and food technology common buckwheat is usually considered as a pseudocereal. In comparison with other cereals buckwheat has a low yield, however, there are some advantages. It is a short-season crop and it does not have

\footnotetext{
${ }^{1}$ Teofil Gavrić*(corresponding author: t.gavric@ppf.unsa.ba), Sabrija Čadro, Drena Gadžo, Mirha Đikić, Muamer Bezdrob, Josip Jurković, Saud Hamidović, Faculty of Agriculture and Food Sciences University of Sarajevo, BOSNIA AND HERZEGOVINA; Zoran Jovović University of Montenegro, Biotechnical faculty, Mihaila Lalića 1, 81000, Podgorica, MONTENEGRO Paper is presented on Green Room Sessions - International Conference, Podgorica 2018 Notes: The authors declare that they have no conflicts of interest. Authorship Form signed online.
} 
particular soil or fertilization requirements. Also, buckwheat can grow at high altitudes (Khan et al., 2013). In its grains buckwheat contains a variety of nutrients, main compounds are proteins, polysaccharides, dietary fibers, lipids, polyphenols, minerals and vitamins (Ahmed et al., 2014). Thanks to the chemical composition, grain of buckwheat is primarily used to obtain high quality flour. Unlike flour of wheat, buckwheat's flour is gluten free (Gadžo et al., 2016.), contains proteins with good balanced amino acids (Selimović et al., 2014), and it is particularly rich in lysine and arginine (Christa and Soral-Śmietana, 2008). Compared to other cereals buckwheat kernel has a higher fiber content.

Buckwheat's flower and leaf in recent years become more popular due to their positive effect on human health. Healing properties of buckwheat are derived from the content of the phenolic compounds. It is believed that the consuming of buckwheat contributes to the alleviation or prevention of many diseases (Tomotake et al., 2001; Kawa et al., 2003; Li et al., 2016).

According to FAO data (FAOStat, 2018), in 2016, it buckwheat was cultivated on an area of 2.37 million hectares globally. The main producers of buckwheat in the world are Russian Federation, China and Ukraine and they have $70 \%$ of the sown areas of the world (Gadžo et al., 2016). In Bosnia and Herzegovina cultivation area for buckwheat is about 1056 ha with an average yield of $1.07 \mathrm{t} \mathrm{ha}^{-1}$ (FAOStat, 2018).

Grain yield and chemical composition of buckwheat depends on a large number of factors, and some of them are variety of buckwheat (Gavrić and Gadžo, 2011; Golob et al., 2016) and agrotechnical conditions of cultivation (Strakšas et al., 2011; Rahimić and Gadžo, 2012). An important role in formation and quality of yield also have weather conditions (Gavrić et all., 2018; Bavec et al., 2002), mainly due to variations in the air temperatures (Strakšas et al., 2011) and precipitation (Glamočlija et al., 2012) during the growing period. Considering that meteorological parameters are changeable, unstable and unpredictable in certain areas for production of buckwheat, the aim of this study was to determine the impact of some metrological parameters on yield and chemical composition in the kernel of buckwheat.

\section{MATERIAL AND METHODS}

Field experiments were conducted in 2011, 2012 and 2013 growing seasons in the village Donje Selo, near Ilijaš. Common buckwheat (variety Darja) originates from Slovenia and it was used in this research. Buckwheat was sown in three different sowing rates: 50 (S1), 80 (S2) and 100 (S2) kg per hectare. Experiment was set up by randomized block method in four repetitions. The size of basic plot was $4.8 \mathrm{~m}^{2}$. The seeds were sown when the soil temperature was 10 ${ }^{\circ} \mathrm{C}$ and the sowing was done manually. During the vegetation, weeds were removed manually. Yield of buckwheat was measured in the field. Total protein, starch, fat, ash, cellulose and phenol contents were determined at Laboratories of the Faculty of Agriculture and Food Science Sarajevo. Content of nitrogen in kernel was determined by kjeldahl method described by ISO 5983 and distillation 
was made by Microkjeldahl apparatus (Foss Kjeltec 2200) to determine kernel nitrogen contents. After measurements, protein content was calculated by multiplying nitrogen contents in kernel with a constant factor of 6.25. Starch was determined by polarimetric method described by Ewers (ISO 6493), contents of lipids were determined by ISO 6492, contents of ash was determined by ISO 5984, and contents of cellulose was determined by Kürschner-Hanack (Kulić and Radojičić, 2011). The total phenolic contents of ethanolic extracts were measured by using of Folin Ciocalteau reagent as described by Bystrická et al. (2010). Statistical analyses were made using SPSS 22 software program.

\section{RESULTS AND DISCUSSION}

In table 1 monthly average air temperature and precipitation amount for the period of the research (2011-2013) is presented. Analysis of weather conditions was done on the basis of data for the weather station Sokolac. During the research period, dry and above average warm weather was recorded. The year 2012 has been particularly contradictory comparing to the climate reference period $\left(1961\right.$ - 1990). In 2012, air temperature was $4.4{ }^{\circ} \mathrm{C}$ higher compared to climate reference period (1961 - 1990). The temperature increase was accompanied by droughts. The minimum amount of precipitation during vegetation period was recorded in August of 2012 (0.6 mm) and 2011 (9.2 mm). The weather conditions in 2013 were more favorable compared to the other two years (2011 and 2012).

Table 1. Average monthly air temperature and amount of precipitation

\begin{tabular}{|c|c|c|c|c|c|c|c|c|c|c|c|c|c|}
\hline \multirow{3}{*}{ Year } & \multicolumn{12}{|c|}{ Month } & \multirow[t]{2}{*}{ Average } \\
\hline & $\mathbf{I}$ & II & III & IV & $\mathbf{V}$ & VI & VII & VIII & IX & $\mathbf{X}$ & XI & XII & \\
\hline & \multicolumn{12}{|c|}{ Average monthly air temperature $\left({ }^{\circ} \mathrm{C}\right)$} & \\
\hline $\begin{array}{c}1961- \\
1990\end{array}$ & -4.8 & -2.2 & 1.6 & 6.4 & 11.4 & 14.3 & 16.0 & 15.5 & 12.0 & 7.2 & 2.1 & -2.8 & 6.4 \\
\hline 2011. & -2.5 & -2.4 & 1.8 & 7.7 & 11.0 & 15.8 & 17.5 & 18.2 & 15.5 & 6.4 & 0.8 & -1.0 & 7.4 \\
\hline 2012. & -4.5 & -7.2 & 3.6 & 7.4 & 10.9 & 18.7 & 20.4 & 19.7 & 15.1 & 9.5 & 6 & -2.8 & 8.1 \\
\hline \multirow[t]{2}{*}{2013.} & -0.7 & 0.0 & 2.3 & 8.9 & 12.5 & 15.6 & 18.1 & 18.5 & 12.3 & 9.4 & 4.7 & -1.6 & 8.3 \\
\hline & \multicolumn{12}{|c|}{ Amount of precipitation(mm) } & Amount \\
\hline $\begin{array}{l}1961- \\
1990\end{array}$ & 53 & 50 & 56 & 62 & 73 & 84 & 73 & 70 & 66 & 66 & 84 & 71 & 805 \\
\hline 2011. & 30.2 & 27.6 & 28.8 & 42.7 & 123 & 62.8 & 82.2 & 9.2 & 36.7 & 59.6 & 23.7 & 100.1 & 626 \\
\hline 2012. & 90.8 & 100.6 & 23.6 & 93.7 & 205.1 & 11.6 & 77.6 & 0.6 & 59.4 & 67 & 50.7 & 80.7 & 861 \\
\hline 2013. & 126.1 & 138.9 & 71.7 & 44 & 121.5 & 41.4 & 28.4 & 70.6 & 108 & 78.5 & 70.8 & 5.7 & 905 \\
\hline
\end{tabular}

Results presented in Table 2. show that yield significantly depends on the year of research and the sowing rate. The results indicated that yield of buckwheat varied from the year to year and ranged from 0.98 (2012) to 1.29 (2013) $\mathrm{tha}^{-1}$. 
Yield in 2013 was relatively high compared to the other two years (2011 and 2012). Buckwheat is a plant which achieves better yields in humid regions and wet years (Milić et al., 2013). Such conditions were not present during 2012 and it was one of the reasons why buckwheat achieved the lowest yields in this year (Table 1. and 2). During this three-year research, the highest monthly temperatures during the vegetation period were recorded in 2012 (Table 1.) and this fact is the second reason why the buckwheat had the low yield in this year. It is known that buckwheat has a long flowering period and that high temperatures have a negative impact on pollination and yield formation. Many studies found a close relationship between drought and yield of buckwheat (Gavrić and Gadžo, 2011; Glamočlija et al., 2012; Popović et al., 2014).

Table 2. Kernel Yield, $\mathrm{t} \mathrm{ha}^{-1}$

\begin{tabular}{|l|c|c|c|c|}
\hline \multirow{2}{*}{ Sowing rate } & \multicolumn{4}{|c|}{ Year of the research } \\
\cline { 2 - 5 } & $\mathbf{2 0 1 1}$ & $\mathbf{2 0 1 2}$ & $\mathbf{2 0 1 3}$ & Average \\
\hline $\mathbf{5 0} \mathbf{~ k g ~ h a}^{-\mathbf{1}} \mathbf{( S 1 )}$ & 0.57 & 0.83 & 1.04 & $0.81^{\mathrm{c}}$ \\
\hline $\mathbf{8 0} \mathbf{~ k g ~ h a}^{-\mathbf{1}} \mathbf{( S 2 )}$ & 0.70 & 1.16 & 1.32 & $1.06^{\mathrm{b}}$ \\
\hline $\mathbf{1 0 0} \mathbf{~ k g ~ h a}^{-\mathbf{1}} \mathbf{( S 3 )}$ & 1.82 & 0.95 & 1.52 & $1.43^{\mathrm{a}}$ \\
\hline Average & $1.03^{\mathrm{b}}$ & $0.98^{\mathrm{b}}$ & $1.29^{\mathrm{a}}$ & \\
\hline
\end{tabular}

Yield of buckwheat also significantly depended on sowing rate and they are in a positive relation. Therefore, the average grain yield in S1 variant was $0,81 \mathrm{t} \mathrm{ha}^{-1}$, and increased to $1,43 \mathrm{t} \mathrm{ha}^{-1}$ in S3 variant. A similar effect of sowing rates was observed in all years of research except in the second year (Table 2). Influence of sowing rates on yield had been proved by many authors (Gavrić et al., 2018; Thakuria and Gogo, 2000).

Buckwheat kernel contains a variety of nutrients and the main compounds are proteins, starch, cellulose, lipids, minerals and phenols. The total content of some components depends on the variety of buckwheat and environmental factors (Christa and Soral-Śmietana, 2008). In this research, it was found that the sowing rates had no significant effect on the chemical composition.

Table 3. Chemical compose of buckwheat's kernel

\begin{tabular}{|c|c|c|c|c|c|c|}
\hline $\begin{array}{c}\text { Year of } \\
\text { research }\end{array}$ & $\begin{array}{l}\text { Crude } \\
\text { protein, \% }\end{array}$ & Starch, \% & $\begin{array}{c}\text { Cellulose, } \\
\text { \% }\end{array}$ & Fat, \% & Ash, \% & $\begin{array}{l}\text { Total } \\
\text { phenols, } \\
\mathbf{m g ~ g}^{-1}\end{array}$ \\
\hline $\mathbf{2 0 1 1}$ & $10.94^{\mathrm{c}}$ & $63.78^{\mathrm{a}}$ & $9.86^{\text {ns }}$ & $2.07^{\text {ns }}$ & $2.20^{\text {ns }}$ & $0.37^{\mathrm{b}}$ \\
\hline $\mathbf{2 0 1 2}$ & $14.26^{\mathrm{a}}$ & $60.71^{\mathrm{b}}$ & $10.55^{\text {ns }}$ & $1.69^{\text {ns }}$ & $2.18^{\text {ns }}$ & $3.67^{\mathrm{a}}$ \\
\hline $\mathbf{2 0 1 3}$ & $12.08^{\mathrm{b}}$ & $62.34^{\text {ab }}$ & $10.07^{\text {ns }}$ & $1.97^{\text {ns }}$ & $2.30^{\text {ns }}$ & $0.35^{\mathrm{b}}$ \\
\hline Average & 12.43 & 62.28 & 10.16 & 1.91 & 2.23 & 1.47 \\
\hline
\end{tabular}

The results of chemical composition show that contents of crude protein and starch significantly depend on the research year. The average contents of crude protein ranged from minimal $10.94 \%$ (2011) to maximal 14.26\% (2012). During 
second year of research (2012), the largest content of crude protein in kernel of buckwheat was detected (14.26\%). Higher content of crude protein was probably caused by lower precipitation levels during vegetation (Table 1.). Increasing protein content in kernel can be explained by the reduction in the content of starch in kernel. If we compare starch content (Table 3) with precipitation levels, it can be concluded that the lowest content of starch (60.71\%) is recorded in the year with smallest amounts of rain during vegetation. The highest starch contents (62.34\% and 63.78\%) were determined in the years with a larger amount of precipitation (2011 and 2013). These results are similar to Erekul and Köhn (2009). They found that lack of rain in some years led to high crude protein contents and low starch contents in kernel of wheat and triticale. Similar observations have been reported by many authors (Vafa et al., 2014; Pierre et al., 2008; Sial et al, 2005).

Observing the results from Table 3 , it can be concluded that contents of cellulose, fats and ash did not depend on any of the research factors. Their content in kernel has been in the range as in the literature (Christa and SoralŚmietana, 2008; Kreft and Germ, 2008).

Total phenols have a vital part in the protection of plants against high or low temperatures (Kreft et al., 2013), droughts (Lim et al. 2012), UV radiation (Kreft et al.,2003; Germ, 2004), pathogens and herbivores (Guo et al., 2011) and their high concentration in plants suggest to environmental stress factors (Stagnari, et al., 2017). The results in Table 3. suggest that concentrations of total phenols depend on the years of the research. During 2012 (3.67 $\left.\mathrm{mg} \mathrm{GAE} \mathrm{g}^{-1}\right)$, buckwheat had about ten times higher total phenol than in 2011 (0.37 $\left.\mathrm{mg} \mathrm{GAE} \mathrm{g}^{-1}\right)$ and 2013 $\left(0.35 \mathrm{mg} \mathrm{GAE} \mathrm{g}^{-1}\right)$. Based on this fact, it can be concluded that buckwheat grew in stressful conditions during 2012, and it synthesized an additional amount of phenol to protect itself. High content was found in the years with a drought and higher average monthly air temperature, and it can be concluded that these factors are the main cause of differences. Kreft et al. (2013) and Lumingkewas et al. (2015) also found that temperature and humidity have effect on concentration of phenol in buckwheat.

\section{CONCLUSIONS}

According to the presented results of the research, influence of meteorological parameters on the yield and chemical composition of common buckwheat during the seasons of 2011, 2012 and 2014, following conclusions can be reached:

-the yield of buckwheat significantly depended on sowing rate and meteorological parameters;

-Increasing sowing rate had positive effect on yield of kernel, but it had no effect on chemical compose of kernel;

-second year of research was with unfavorable weather conditions (drought and high temperature) which resulted in low average yield;

-contents of crude protein, starch and total phenol in kernel depended on meteorological parameters. 
-high content of protein and total phenols was recorded in the year with relatively unfavorable weather conditions;

-drought at 2012 year significantly caused a reduction in contents of starch in kernel.

\section{REFERENCES}

Ahmed, A., Khalid N., Ahmad A., Abbasi N., Latif M., Randhawa M. (2014). Phytochemicals and biofunctional properties of buckwheat: A review. The Journal of Agricultural Science, 152(3): 349-369.

Bavec, F., Pusnik S., Rajcan I. (2002). Yield performance of two buckwheat genotypes grown as a full-season and stubble-crop. Rost. Vyroba 48 :351-355.

Bystrická, J., Vollmannová, A., Margitanová, E., Čičová, I. (2010). Dynamics of polyphenolic formation in different plant parts and different growth phases of selected buckwheat cultivars. Acta Agric. Slov., 95 (3): 225-229.

Christa, K., Soral-Śmietana, M. (2008). Buckwheat Grains and Buckwheat Products Nutritional and Prophylactic Value of their Components - a Review. Czech J. Food Sci. 26 (3): 153-162.

Erekul, O., Köhn, W. (2006). Effect of Weather and Soil Conditions on Yield Components and Bread-Making Quality of Winter Wheat (Triticum aestivum L.) and Winter Triticale (Triticosecale Wittm.) Varieties in North-East Germany. Journal of Agronomy and Crop Science, 192: 452-464.

FAO (2018). http://www.fao.org/faostat/en/\#data/QC 5.06.2018.

Gadžo D., Đikić M., Oručević-Žuljević S., Gavrić T., Grahić J. (2016). Proizvodnja heljde u brdsko planinskim područjima - dosadašnja iskustva i budući izazovi. Simpozij unapređenje poljoprivrede, šumarstva i vodoprivrede u kraškim, brdskim i planinskim područjima - racionalno korištenje i zaštita, ANUBiH, Sarajevo, BiH

Gavrić T., Gadžo D. (2011). Yield and chemical composition of seeds of common buckwheat and tartary buckwheat by various cultivation technologies. Works of the Faculty of Agriculture University of Sarajevo, 61 (1): 7-17.

Gavrić T., Gadžo D., Đikić M., Bezdrob M., Čadro S., Bašić F. (2018). Effects of plant density on the yield and total phenolic contents of tartary buckwheat. IX International Scientific Agricultural Symposium "Agrosym 2018". Jahorina, BiH

Glamočlija, Đ., Ćosić, Z., Dražić, S., Ikanović, J., Milutinović, M., Đokić, J. (2012). Impact agroecological conditions and land on the morphological features and yield Fagopyrum esculentum. Proceedings of XXVI Conference of Agronomists, Veterinarians, Technologists and Agricultural Economists. 18 (1-2): 71-77

Golob, A., Gadžo D., Stibilj V., Djikić M., Gavrić T., Kreft I., Germ M., (2016). Sulphur interferes with selenium accumulation in Tartary buckwheat plants. Plant Physiology and Biochemistry 108.

Guo, X., Ma Y., Parry J., Gao J., Yu L., Wang M. (2011). Phenolics content and antioxidant activity of tartary buckwheat from different locations. Molecules, 16 12, 9850-67. 
ISO 5983-2. (2005). International Organization for Standardization, Animal feeding stuffs - Determination nitrogen content and calculation of crude protein content.

ISO 5984. (2002). International Organization for Standardization, Animal feeding stuffs - Determination of ash.

ISO 6492. (1999) International Organization for Standardization, Animal feeding stuffs Determination of fat content.

ISO 6493. (2000) International Organization for Standardization, Animal feeding stuffs Determination of starch content - Polarimetric method.

Lim J. H., Park K. J., Kim B.K., Jeong J.W., Kim H.J., (2012). Effect of salinity stress on phenolic compounds and carotenoids in buckwheat (Fagopyrum esculentum M.) sprout. Food Chem. 135:1065-70

Kawa, J.M., Taylor, C.G., Przybylski, R. (2003). Buckwheat concentrate reduces serum glucose in streptozotocin-diabetic rats. Journal Agric. Food Chemistry. 51(25).

Khan F., M. Arif, T. U. Khan, M. I. Khan, J. A. Bangash, (2013). Nutritional evaluation of common buckwheat of four different villages ofgilgit-baltistan. ARPN Journal of Agricultural and Biological Science, Vol. 8. No. 3. ISSN 1990-6145.

Kreft, I., Fabjan N., Germ M. (2003). Rutin in buckwheat - Protection of plants and its importance for the production of functional food. Fagopyrum 20: 7-11.

Kreft, I., Germ, M. (2008). Organically grown buckwheat as a healthy food and a source of natural antioxidants. Agronomski Glasnik 4: 397-406.

Kreft, S., Janeš, D., Kreft, I. (2013). The content of fagopyrin and polyphenols in common and tartary buckwheat sprouts. Acta Pharm. 63:1-8.

Kulić, G., Radojičić V. (2011). Analysis of cellulose content in stalks and leaves of large leaf tobacco. Journal of Agricultural Sciences. 56 (3).

Li, J., Gong, F., Li, F. (2016). Hypoglycemic and hypolipidemic effects of flavonoids from tatary buckwheat in type 2 diabetic rats. Biomedical Research. 27(1): 132137.

Lumingkewas, A., Koesmaryono, Y., Aziz Impron, S., Sugimoto, H. (2015). The Influence of Temperature to Rutin Concentration of Buckwheat Grains in Humid Tropic. IJSBAR 20(1): 1-9.

Milić, V., Govedarica B., Šilj M., , Berjan S., Jovovic Z. (2013). Effect of agroecological conditions on grain yield in some genotypes of buckwheat. IV International Scientific Agricultural Symposium "Agrosym 2013". Jahorina, BiH.

Pierre C. S., Petersona J., Rossa A., Ohma J., Verhoevena M., Larsona M., Hoefera B. (2008). White wheat grain quality changes with genotype, nitrogen fertilization, and drought stress. Agron. J. 100: 414-420.

Popović, V., V. Sikora, J. Berenji, V. Filipović, Ž. Dolijanović, J. Ikanović, D. Dončić, (2014). Analysis of Buckwheat production in the World and Serbia. Economics of Agriculture 61. 1.

Rahimić, A., Gadžo D., (2012). The influence of the location and sowing term on the yield and qualitative properties of buckwheat. Works of the Faculty of Agricultural and Food Sciences University of Sarajevo. 62 (1) 15-28. 
Selimović A., Miličević D., Jašić M., Selimović A., Đurđica Đ., Pešić T. (2014). The effect of baking temperature and buckwheat flour addition on the selected properties of wheat bread. Croat. J. Food Sci. Technol. 6 (1) 43-50.

Sial, M. A., Arain M. A., Naqavi, S. K., Dahoti M. M., Nizamani, N. A.(2005). Yield and qualityparameters of wheat genotypes as affected by sowing dated and high temperature stress, Pak. J. Bot. 37 (3): 575-584.

Stagnari, F., Galieni, A., D’Egidio, S., Falcinelli, B., Pagnani, G., Pace, R., Pisante, M., Benincasa, P. (2017). Effects of sprouting and salt stress on polyphenol composition and antiradical activity of einkorn, emmer and durum wheat. Italian Journal of Agronomy, 12(4): 293-301.

Strakšas, A., Kučinskas V., Vaiciukevičius E. (2011). The investigation and comparison of buckwheat harvesting technologies in Lithuania. Agricultural engineering. Research papers. 43 (1): 44-59.

Thakuria, K., Gogoi P.K. (2000). Effect of row spacing, seed rate and fertility level on yield of buckwheat (Fagopyrum esculentum). Indian Journal of Agronomy. 45 (3) 624-627.

Tomotake, H., Shimaoka, I., Kayashita, J., Nakajoh, M., Kato, N. (2001). Buckwheat protein suppress plasma cholesterol more strongly then soy protein isolate in rats by enhancing fecal excretion of steroids. Proc. 8th int. Symp. Buckwheat. Chunchon, Koreja. 587-594.

Vafa P., Naseri R., Moradi M. (2014). The Effect of Drought Stress on Grain Yield, Yield Components and Protein Content of Durum Wheat Cultivars in Ilam Province, Iran. International Journal of Biological, Veterinary, Agricultural and Food Engineering. 8 (6): 619-624. 